\title{
How Are Continuous Quality Improvement (CQI) Approaches Used in Evaluating Management Development Programs? A literature review
}

\author{
LeIGH-ANN ONNIS, Marcia HaKendorf, Komla TSEY
}

Leigh-ann onnis - James Cook University Cairns Campus - College of Business, Law \& Governance, Cairns, Queensland 4870, Australia

Marcia Hakendorf - CRANAplus - Professional Services, Adelaide, South Australia, Australia Komla Tsey - James Cook University - College of Arts, Society \& Education, Cairns, Queensland, Australia

Correspondence: leighann.onnis@jcu.edu.au

\section{Abstract}

Aim: The aim of the review was to examine the characteristics of studies that use CQI approaches to evaluate management development programs; and to synthesise the findings to understand how CQI approaches are being used to evaluate the effectiveness of management development programs.

Method: A scoping review of the literature was conducted in a manner consistent with the Preferred Reporting Items for Systematic Reviews and Meta-Analyses (PRISMA) statement. The matches were screened by title and abstract using the inclusion criteria, leading to a full paper review of 48 papers. Of these, the 14 papers found to meet the inclusion criteria for the scoping review were independently reviewed and analysed by two of the authors.

Findings: The review revealed the ways in which CQI approaches were used in evaluating management development programs highlighting the role of context, predetermined competencies and participatory
CQI approaches. Participatory CQI approaches including on-the-job application of learning provided opportunities for participants to learn through CQI activities associated with action learning and CQI feedback cycles.

Conclusion The authors concluded that evaluations using participatory CQI approaches are better positioned to report more comprehensively on the benefits of management development programs when they include the competencies required to be successful in the context within which the manager is working. Future directions for research in this area include an examination of the microsystem context to determine whether the required management competencies associated with remoteness differ from other contexts.

Keywords: CQI, continuous improvement, program evaluation, management, development 


\section{INTRODUCTION}

More than a decade has passed since Drucker observed that large healthcare organisations are the most complex institutions in history, and that small healthcare centres are barely manageable.[1] Yet, the complexity of health services, together with the increasing demands placed on health managers remains relevant.[1] With predicted health workforce shortages globally, strong leadership and management are essential, particularly in regions that traditionally experience workforce shortages, if they are to deliver quality health services. The $\mathrm{WHO}$ [2] policy recommendations about improving access to health workers in areas where workforce shortages are common (e.g. rural and remote areas) encourages all countries to strengthen leadership development programs and create supportive workplaces.[2] Furthermore, the WHO suggest that the geographical context requires specific interventions 'because addressing rural and remote areas will also address the needs of underserved populations more broadly.' [2, p.9] Similarly, CRANAplus[3] and the National Rural Health Alliance[4] report specific issues associated with the characteristics of remoteness. Therefore, a focus on improving management capability, particularly for managers working in remote areas where remoteness exacerbates the difficulties in accessing management education, training and support will contribute to health service improvements. [4-6]

The challenges for managers stem from widespread health system reform, health service restructuring, economic pressure from aging populations, increased demand for health services and funding reforms.[7,8] In Australia, a review of health service management raised concerns about widespread skill deficiencies, particularly a need to develop skills in building and nurturing relationships.[8] This is not restricted to health services, with a major review (Karpin Report) into ways of improving management development in Australia into the 21st century raising awareness about the relationship between management capability and organisational performance. The Karpin Report highlighted the critical role of education and professional development, particularly, improved non-technical 'soft' skills (e.g. managing people, communication) in ensuring managers have the skills needed to be effective at any level of management. [9]

\section{Management Development}

Management development refers to a planned process of training, or specifically chosen capacity building activities, resulting in management capabilities benefitting the organisation. [10] Often, management development is self-directed with benefits experienced directly by the manager, and indirect benefits filtering through to health services. Often, evaluations reinforce individual benefits focusing on the participant's experience and satisfaction, missing the opportunity to evaluate changes in their performance as a manager and the quality of health services. [11,12] external private practices based on set fees for each the item of care provided. [4]

\section{Continuous Quality Improvement (CQI) approaches}

Generally, CQI is viewed as an opportunity to reflect on the success of an activity and how it could be improved. More specifically, program evaluation is a process of assessing 'the total value of training: that is the cost-benefit and general outcomes, which benefit the organization as well as the value of the improved performance of those who have undertaken training.' $[11$, p.14] Therefore, it is 
imperative that management development program evaluations measure improvements in individual performance and service quality. CQI approaches are often used to bridge gaps between best practice evidence and what happens in practice with a view to improving population level health outcomes.[13] Hence, CQI is used in identifying problems, developing solutions and evaluating changes to ensure that education and training programs meet the needs of the participant, provide cost-effective management development solutions for organisations, and lead to service improvements for customers. $[13,14]$

The CQI literature highlights the influence of context with some studies attributing variation of results to differences in the context for the CQI initiatives.[15-17] These contextual or within service factors are described as microsystems.[18] Microsystems are defined as 'small groups of people who regularly work together to provide care.'[17, p.503] In microsystems, context includes the characteristics of individuals, the organisation, the physical, and cultural environment (e.g. supportive clinical leadership, workforce stability).[16,17] There is limited understanding about how the drivers of CQI effectiveness in a microsystem interact with one another and/or with other contextual factors to achieve the desired impacts in primary health care services.[12,17] Despite this, it is believed that lessons learned in one microsystem, provide valuable insights for other microsystems with similar characteristics.16 Hence, this scoping review contributes to the literature about how CQI approaches are used in evaluating programs for a subgroup (managers) who have considerable influence over their particular microsystem.
This scoping review analysed and synthesised the existing literature to answer the question, How are CQI approaches used in evaluating the effectiveness of management development programs? There were few health service specific management development programs reported in the literature, so a broad scope was necessary in an effort to identify literature that describes empirical studies with management development programs containing general management and/or soft management skills training; areas of need identified in the health service management literature.[2,8] Therefore, the aim of this scoping review is to examine the characteristics of studies that use CQI approaches to evaluate management development programs, and to synthesise the findings to understand how CQI approaches are being used to evaluate the effectiveness of management development programs.

\section{METHODS}

A scoping review of the literature was conducted using accepted scoping review methods and in a manner consistent with the Preferred Reporting Items for Systematic Reviews and Meta-Analyses (PRISMA) Statement (Figure 1).[19,20,21] The literature search used a combination of the search terms 'evaluat*', 'manage*', 'program', 'training' using One Search which searched multiple databases including: informit, CINAHL, EBSOHost, OvidSP, OvidMP, PubMED, ProQuest and the Wiley online library. The literature searches resulted in variable matches across search terms; however, a larger number of matches did not result in a higher number of articles that met the inclusion criteria. Next, a search using the same search terms was conducted on the Emerald Insight and the Cochrane Library databases. An additional search of systematic 
reviews was conducted using the Cochrane Library database, which identified two systematic literature reviews, both of which authors $\mathrm{LO}$ and $\mathrm{MH}$ agreed did not meet the inclusion criteria.

The matches were screened by title and abstract against the inclusion criteria:

a) Peer reviewed

b) Published in English

c) Published between 1/10/1997-

$1 / 10 / 2017$

d) Used a CQI approach to evaluate a management development program that included general management and/or 'soft skills' management training.

All matches were screened and 48 papers were included in the full paper review. These papers were read in full by author LO, with 14 papers selected for the scoping review (Figure 1). While quality assessment does not usually form part of a scoping review, the requirement that the selected papers were published in peer reviewed journals was a proxy for research quality. $[19,20]$ Authors LO and MH agreed that the 14 papers selected met the inclusion criteria for the scoping review. The review commenced with an analysis of the broader characteristics of the publications using the key characteristics (Table 1 and Table 2) developed by author LO through an iterative process. To minimise researcher bias, authors $\mathrm{LO}$ and $\mathrm{MH}$, independently reviewed and analysed the selected papers using the preidentified key characteristics and resolved the small proportion (approx. 5\%) of coding disagreements through a consensus-seeking procedure. Through reviewing the papers and discussing the coding together, interrater differences were addressed and resolved.

\section{RESULTS}

\section{Characteristics of the studies}

An examination of the selected publications illustrated the diversity in characteristics of the management development programs (Table 1). An analysis of the characteristics highlighted the similarities and differences in management programs from across the globe: United Kingdom (UK) and Ireland, Europe (Netherlands, Sweden, Serbia), Asia (China, Iran), Canada and the United States of America (USA). There were no Australian studies; however, one contained an Australian program customised for managers in China. The programs ranged from ten days to two years with $43 \%$ less than one year, $29 \%$ one year, $14 \%$ more than one year, and for $14 \%$ the duration was not reported. The studies were across four industries (health, hospitality, insurance and gaming), in both government organisations and private organisations. Only two were pilot studies; however, many of the studies were small (half had less than 60 participants). Many (43\%) were accredited training programs, with the remainder being non-accredited training programs. While many $(43 \%)$ did not report how participants were selected; of those that reported the selection process, most frequently (43\%) participants were nominated by senior management. Two studies provided training for all managers in the organisation, and for another, managers self-nominated.

Most frequently, the studies were mixed methods (43\%), followed by quantitative (36\%) and qualitative (21\%).

Overall, the studies reported that the programs were developed to achieve three aims: provide managers with qualifications; improve management capacity, knowledge and/or skills; and to improve retention. The evaluations of the management programs aimed to examine: the benefits of the project 
undertaken in the study (including the returns from the program); the effectiveness of the CQI evaluation approach used; the aspects of the programs that influenced its effectiveness; an improvement in management skills and capacity; and organisational level improvements. Notably, the aim of the evaluation was not always consistent with the aim of the program (e.g. Adams and Waddle [11] evaluated the returns, including the impact of outputs on profitability, for a program that aimed to provide managers with management qualifications).
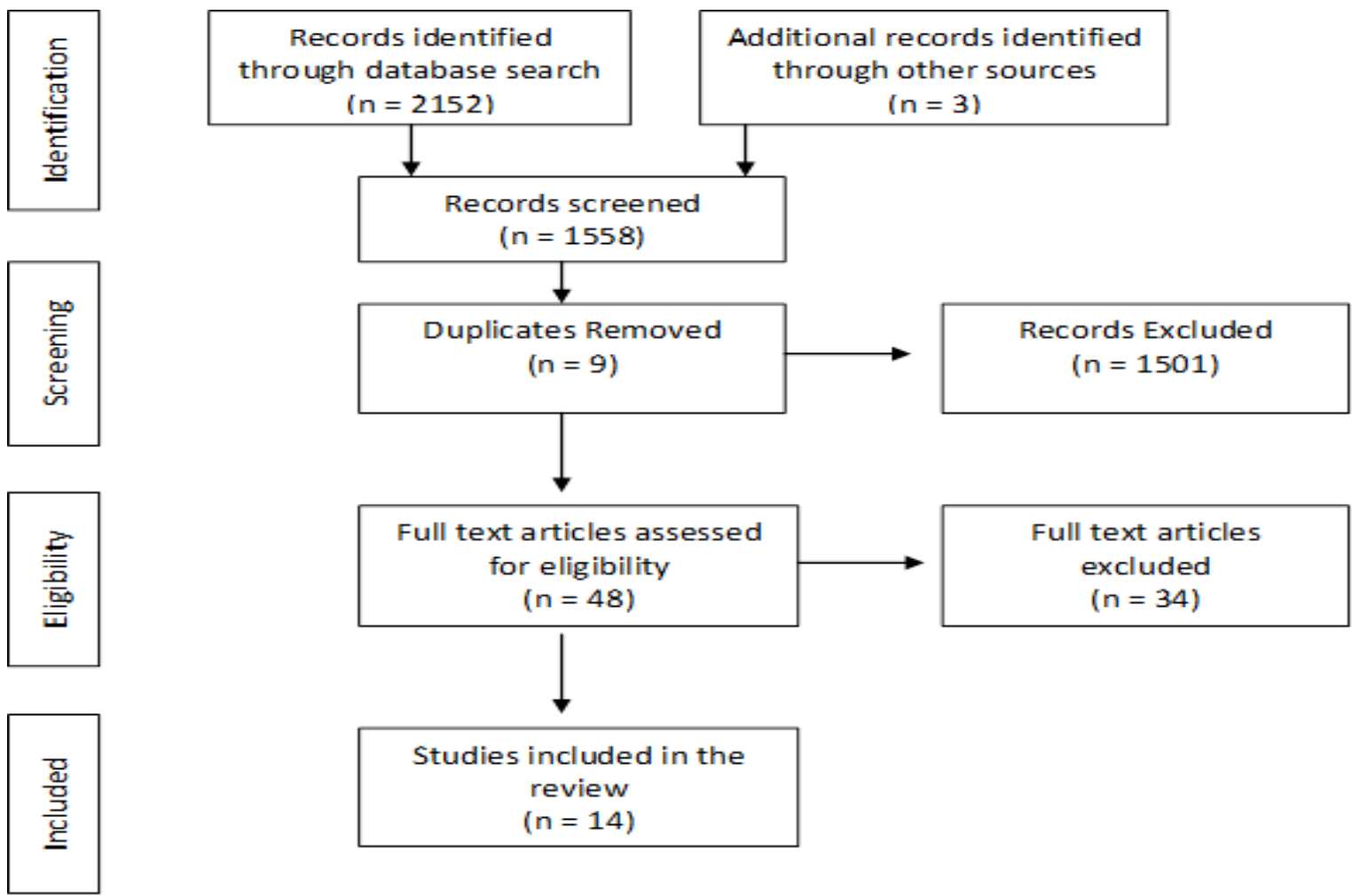

Figure 1: Scoping review process using the PRISMA

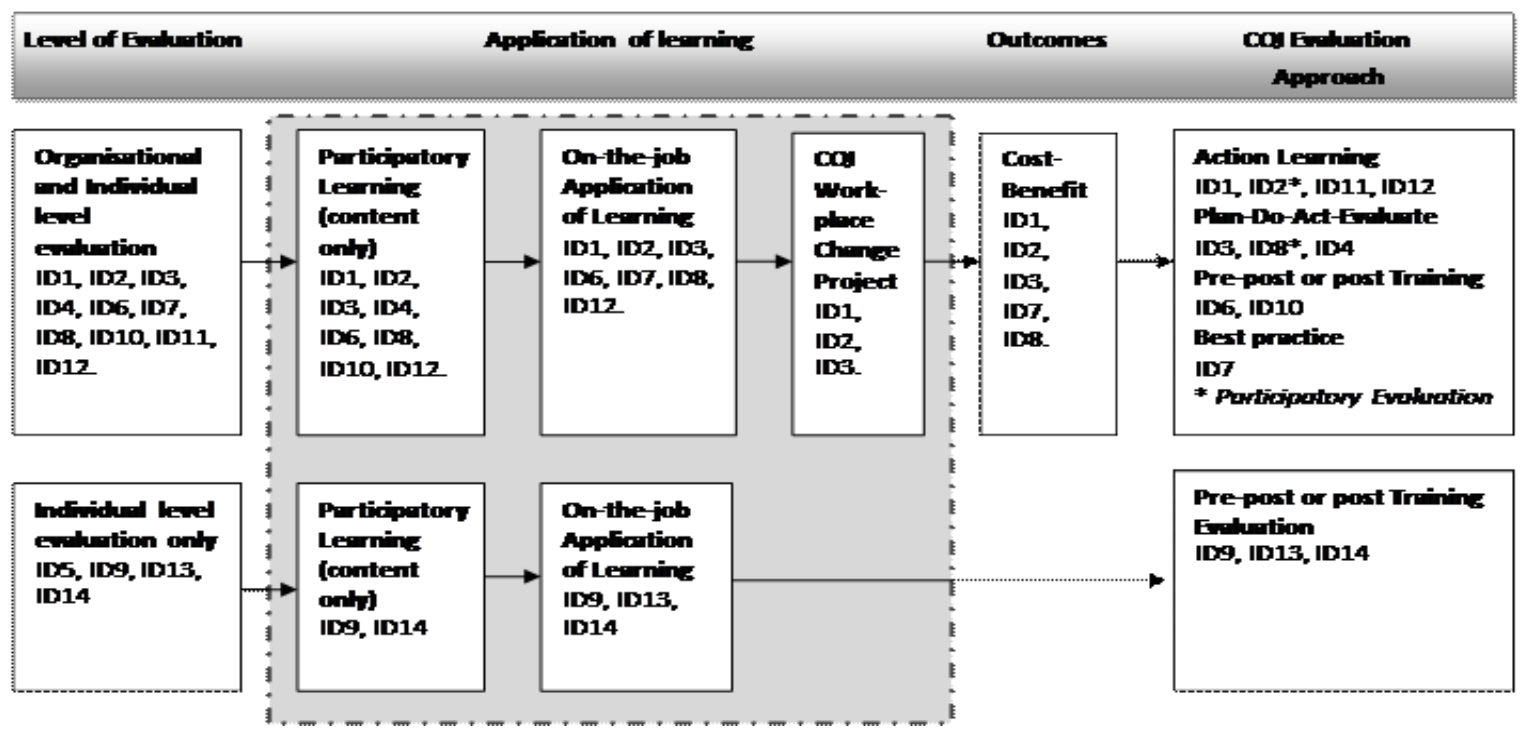

Figure 2: CQI approaches to management development program evaluations 
Six studies used predetermined competencies and measured the participant's progress using these competencies. Four of these studies (three in USA and one in Serbia) were conducted with health managers. The predetermined competencies contained in the studies prescribed a variety of competencies presented as two skillsets: soft management skills and hard management skills (Table 2).

\section{Context}

The scoping review sought to consider the influence of context. Unfortunately, it was not possible to consider geographical context as the selected publications did not provide sufficient information to determine whether the managers worked in urban, rural or remote locations. However, context was raised in six studies. Yapping and Stanton [22, p.166] reported that contextual issues may arise from cultural differences in management education explaining that 'China has been slow to develop the concept of student participation.' Omar et al. [23, p.10] reported that not collecting information about context from respondents 'made it impossible to assess to what extent reported changes (or not) in practice were related to the training programme or to factors in the organizational environment.' Wallis and Kennedy [24] found that context may influence the manager's success in workplace application of skills. Similarly, Fealy et al. [25, p.331] emphasised the importance of evaluating 'the expression of these competencies in context, i.e. in the everyday performance of the leader's professional role'; and Steensma and Groeneveld [26, p.331] proposed that analysis 'should lead to cumulative knowledge of causal connections between characteristics of persons, interventions, and contexts.' Finally, Holmberg et al. [27, p.165] explained that their quasi-experimental design was 'vulnerable to a range of contextual influences'. Hence, context creates both interconnectivity and complexity for program evaluations.

\section{CQI approaches}

CQI approaches are being used to evaluate management development programs at the individual and organisational level. There were a variety of CQI approaches, reported, including: action learning (29\%); CQI feedback cycles (e.g. learn-apply-feedback-review, plandevelop-implement-evaluate) (14\%); staged continuous learning approaches (7\%); best practice (7\%); pre/post training evaluation (14\%); and post training evaluation (29\%) (Table 3). Of the ten programs that included an on-the-job component, seven evaluated at an individual and organisational level, using action learning (43\%), CQI feedback cycles (29\%); best practice (14\%) and post training evaluation (14\%). Further, the programs using a CQI project to demonstrate the application of skills used either action learning (67\%) or a CQI feedback cycle (33\%).

Ten studies (71\%) used participatory approaches for learning and skill development; yet, only two studies (14\%) used participatory approaches in evaluating the program. While five studies (36\%) reported conducting a costbenefit analysis, only four reported tangible organisational benefits, such as 'One of the work-based project outcomes provided an immediately workable solution and in turn it is estimated has saved the WPLC $£ 1.5$ million in development and implementation costs'[11, p.20] and 'With all salary/benefit and program costs compared to these dollar savings, the 2012-2013 PLA yielded a 106 percent ROI.' [28, p.404]

Stratifying the selected publications by level of evaluation (individual, or individual and organisational), and then following the evaluation process from program content (e.g. 
participatory learning approaches) and on-thejob application of skills, through to outcomes (e.g. cost-benefit analysis) and CQI evaluation approach reveals how CQI approaches are being used (Figure 2). Of interest to this review, three studies evaluated management development programs at both the organisational and individual level and included the implementation of a CQI project. These same three studies, as well as two others, evaluated cost-benefits as an outcome for the program. Furthermore, two of the studies that evaluated for cost-benefits included a participatory $\mathrm{CQI}$ approach to evaluation (Figure 2).

\section{DISCUSSION}

The review revealed that the most compelling evidence for the effectiveness of management development programs arises from studies using participatory CQI approaches for evaluating on-the-job application of skills leading to organisational benefits. Further, the studies that included the development and implementation of a CQI project not only provided for real-world application of skills, they provided an opportunity to measure organisational impact, including cost-benefits. The synthesis highlighted three factors to consider when using CQI approaches to evaluate management development programs: context, core competencies, and participatory CQI approaches to evaluation.

\section{Context}

The review suggests that both organisational and ethnically-based cultural contexts influence the implementation and evaluation of management development programs. $[16,17,22-24]$ Some organisational cultures nurture real-world skill development, are open to change and create safe, supportive environments for managers to practice and refine their skills; however, some are not. $[17,18,29]$

The review contained a study where a participatory approach was not compatible with traditional Chinese culture highlighting the importance of considering the compatibility of participatory CQI approaches for programs that contain cross-cultural groups. Particularly, where western perspectives of management are presented to participants from non-westernised cultures. [22] Also, evaluations should consider the cultural context when employees are asked to provide feedback about their manager's performance as it may be contrary to culturally accepted behaviour (e.g. respect for a hierarchy, fear of losing their job). Therefore, it is essential that management development programs are customised to ensure that they use contextually and culturally responsive participatory CQI evaluation approaches.

\section{Core competencies}

Core competencies recommend the skills needed for a manager to perform at a level that meets organisational and customer expectations. Few of the selected studies used pre-determined competencies in their evaluations; despite many credentialing bodies and professional organisations having frameworks or models for their particular industry and/or profession. [30-32] Management competencies are categorised as 'soft' management skills or 'hard' management skills. $[29,33]$ Hard management skills are tangible; therefore, more easily evaluated. Hard business skills include: accounting, computer literacy, and technical knowledge to operate equipment. In contrast, soft skills are abstract and generally harder to evaluate; however, they are important skills for leaders and managers. [29,33] Soft management skills include: self-awareness, 
communication, emotional intelligence, selfregulation, and social skills. [29,33] Recently, there has been an increased focus on developing soft skills in managers. This focus on improving soft management skills for health managers is congruent with the competencies recommended by professional and credentialing bodies. $[1,8,30]$ Common sense suggests that using health service management competency frameworks for management development programs will contribute to improve quality health services.

\section{Participatory CQI approaches}

The review provided strong evidence about the benefit of participatory CQI approaches to learning and evaluation. Further, programs that contained on-the-job application of skills were better placed to demonstrate costbenefits and return on investment (ROI). Hence, evaluating programs using predetermined competencies, to the level of costbenefit provides a robust and economically sensible method of evaluation. To achieve this end, management development programs must be developed, implemented and evaluated in a manner that collects the data required for this level of analysis. The findings from this synthesis suggest that one way to do this is through participatory CQI approaches measuring outcomes against predetermined competencies, with an on-the-job component to assess the application of skills from multiple perspectives, over time, in a real-world context.

\section{Future directions}

The review revealed a dearth of information about management development programs specifically developed for geographically remote regions suggesting that an opportunity exists to explore the role that context plays for managers in this microsystem. Further, an examination of these microsystems could include investigation into whether specific competencies are required for managers working in remote health services; and whether management competencies differ by context (e.g. country, region, and/or ethnically-based culture). The findings would have international relevance and could inform the development of a framework that specifies competencies required for managers in geographically remote regions.

\section{LIMITATIONS}

The inclusion criteria limited selection to articles published in English possibly excluding some relevant studies. Also, the quality check for the review required articles to be peer reviewed, restricting the use of grey literature. This excluded articles from industry magazines and journals as they lacked the information needed to determine the validity and reliability of the information reported.

\section{CONCLUSION}

Evaluating management development programs beyond the level of participant satisfaction is costly and time consuming. However, to know the effectiveness of a program it is imperative to conduct evaluations that capture how well the program achieved the desired outcomes as well as the cost-benefit of the program. This scoping review set out to examine the ways in which CQI approaches are used in evaluating the effectiveness of management development programs. The findings suggests that participatory CQI approaches to management development program implementation and evaluation can contribute to improvements in the quality of healthcare.[17] Through a synthesis of the findings, the authors conclude that evaluations using participatory CQI approaches are better positioned to report more comprehensively on the benefits of management development programs when they include the competencies required to be successful in the context within which the manager is working. 


\section{Acknowledgements}

This study was undertaken under the auspices of the Centre of Research Excellence: An Innovation Platform for Integrated Quality Improvement in Indigenous Primary Health Care (CRE-IQI, funded by the NHMRC ID 1078927). The views expressed in this publication are those of the authors and do not

\section{References}

1. Stefl ME. Common competencies for all healthcare managers: the Healthcare Leadership Alliance model. Journal of Healthcare Management 2008; 53: 360-374.

2. World Health Organisation (WHO). Increasing access to health workers in remote and rural areas through improved retention. WHO; 2010. Available: <http://www.who.int/hrh/retention/guidelines/en/> (Accessed 27/03/18)

3. Malone G, Cliffe C. A Framework for Remote and Isolated Professional Practice. CRANAplus; August 2014. Available:

$<$ https://crana.org.au/resources/practice/remotepractice/> (Accessed 27/03/18)

4. National Rural Health Alliance. Supporting Health Service Managers in Rural and Remote Australia. September 2004. Available: < http://ruralhealth.org.au/sites/default/files/positionpapers/position-paper-04-09-21.pdf> (Accessed 27/03/18)

5. Hegney D, McCarthy A, Rogers-Clark C, Gorman D. Retaining rural and remote area nurses. The Queensland, Australia experience. The Journal of Nursing Administration 2002; 32: 128-35.

6. Onnis L, Pryce J. Health professionals working in remote Australia: a review of the literature. Asia Pacific Journal of Human Resources 2016; 54: 32-56.

7. Isouard G, Martins JM. Health service managers in Australia: Progression and evolution. Asia Pacific Journal of Health Management 2014; 9: 35-52.

8. Martins J, Isouard G. An evidence-based framework: Competencies and skills for managers in Australian health services. Asia Pacific Journal of Health Management 2015; 10: 8-23.

9. Innovation \& Business Skills Australia (IBSA). Karpin Report Revisited: Leadership and Management Challenges in Australia. South Australia: IBSA; 2011. Available:

<https://store.ibsa.org.au/sites/default/files/media/Kar pin\%20Revisited,\%20Leadership\%20and\%20Manageme nt\%20Challenges\%20in\%20Australia.pdf> (Accessed 27/03/18) necessarily reflect the views of the funding agencies. The authors also acknowledge inkind support from James Cook University, the Cairns Institute and CRANAplus.

10. Becker K, Bish A. Management development experiences and expectations: informal vs formal learning. Education \& Training 2017; 59: 565-78.

11. Adams D, Waddle C. Evaluating the return from management development programmes: individual returns versus organizational benefits. International Journal of Contemporary Hospitality Management 2002; 14: 14-20.

12. Schierhout G, Hains J, Si D, Kennedy C, Cox R, Kwedza R, O'Donoghue L, Fittock M, Brands J, Lonergan $K$, Dowden M, Bailie R. Evaluating the effectiveness of a multifaceted, multilevel continuous quality improvement program in primary health care: developing a realist theory of change. Implementation science 2013; 8: 119.

13. Bailie R, Bailie J, Broughton E, Larkins S. Editorial: Continuous Quality Improvement (CQI)-Advancing Understanding of Design, Application, Impact, and Evaluation of CQI Approaches. Frontiers in Public Health 2017; 5.

14. Dunne S, Lunn C, Kirwan M, Matthews A, Condell S. Planning and Selecting Evaluation Designs for Leadership Training: A Toolkit for Nurse Managers and Educators. Journal of Professional Nursing 2015; 31: 475-81.

15. Foy R, Eccles MP, Jamtvedt G, Young J, Grimshaw JM, Baker R. What do we know about how to do audit and feedback? Pitfalls in applying evidence from a systematic review. BMC Health Services Research 2005; 5: 50 .

16. Gardner K, Bailie R, Si D, O'Donoghue L, Kennedy C, Liddle H, Cox R, Kwedza R, Fittock M, Hains J, Dowden $\mathrm{M}$, Connors $\mathrm{C}$, Burke $\mathrm{H}$, Beaver $\mathrm{C}$. Reorienting primary health care for addressing chronic conditions in remote Australia and the South Pacific: Review of evidence and lessons from an innovative quality improvement process. Australian Journal of Rural Health 2011; 19: 111-7.

17. Kaplan HC, Brady PW, Dritz MC, Dritz MC, Hooper DK, Linam WM, Froehle CM, Margolis P. The Influence of Context on Quality Improvement Success in Health Care: A Systematic Review of the Literature. The Milbank Quarterly 2010; 88: 500-59. 
18. Larkins S, Woods CE, Matthews V, Thompson SC, Schierhout G, Mitropoulos M, Patrao T, Panzera A, Bailie, RS. Responses of Aboriginal and Torres Strait Islander primary health-care services to continuous quality improvement initiatives 2016; 3: 288.

19. Weeks LC, Strudsholm T. A scoping review of research on complementary and alternative medicine 21. Moher D, Liberati A, Tetzlaff J, Altman DG. Preferred reporting items for systematic reviews and metaanalyses: the PRISMA statement. BMJ 2009; 339: 332336.

22. Yaping D, Stanton P. Evaluation of the health services management training course of Jiangsu, China. Australian Health Review 2002; 25: 161-70.

23. Omar M, Gerein N, Tarin E, Butcher C, Pearson S, Heidari G. Training evaluation: a case study of training Iranian health managers. Human Resources for Health 2009; 7: 20.

24. Wallis A, Kennedy KI. Leadership training to improve nurse retention. Journal of Nursing Management 2013; 21: 624-32.

25. Fealy GM, McNamara MS, Casey M, O'Connor T, Patton D, Doyle L, Quinlan C. Service impact of a national clinical leadership development programme: findings from a qualitative study. Journal of Nursing Management 2015; 23: 324-32.

26. Steensma H, Groeneveld K. Evaluating a training using the "four levels model". Journal of Workplace Learning 2010; 22: 319-31.

27. Holmberg R, Larsson M, Bäckström M. Developing leadership skills and resilience in turbulent times. Journal of Management Development 2016; 35: 154-69.
(CAM) and the mass media: looking back, moving forward. BMC Complementary and Alternative Medicine 2008; 8: 43.

20. Grant MJ, Booth A. A typology of reviews: an analysis of 14 review types and associated methodologies. Health Information \& Libraries Journal 2009; 26: 91-108.

28. Throgmorton C, Mitchell T, Morley T, Snyder M. Evaluating a physician leadership development program - a mixed methods approach. Journal of Health Organization and Management 2016; 30: 390-407.

29. Charoensap-Kelly P, Broussard L, Lindsly M, Troy M. Evaluation of a Soft Skills Training Program. Business and Professional Communication Quarterly 2016; 79: 15479.

30. Australasian College of Health Service Management (ACHSM). ACHSM Master Health Service Management Competency Framework. ACHSM; 2016. Available: <https://achsm.org.au/Documents/Education/Compete ncy\%20framework/2016_competency_framework_A4_f ull_brochure.pdf> (Accessed 28/03/18)

31. West M, Smithgall L, Rosler G, Winn E. Evaluation of a nurse leadership development programme. Nursing Management 2016; 22: 26.

32. Saleh SS, Williams D, Balougan M. Evaluating the Effectiveness of Public Health Leadership Training: The NEPHLI Experience. American Journal of Public Health 2004; 94: 1245-9.

33. Ibrahim R, Boerhannoeddin A, Bakare KK. The effect of soft skills and training methodology on employee performance. European Journal of Training and Development 2017; 41: 388-406. 
Table 2: Competencies used to evaluate management development programs

\begin{tabular}{|c|c|c|}
\hline \multirow{4}{*}{ 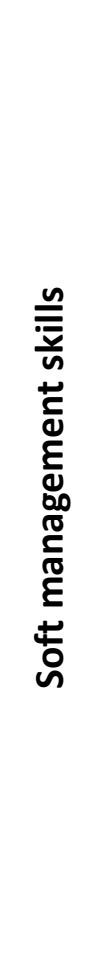 } & $\begin{array}{l}\text { Self-awareness } \\
\text { and } \\
\text { Self-development }\end{array}$ & $\begin{array}{l}\text { Emotional Intelligence (ID3) } \\
\text { Creating a leader in yourself (ID5, ID11) } \\
\text { Professional self-development (ID9) } \\
\text { Organising and time management (ID9) } \\
\text { Self-development and initiative (ID11) }\end{array}$ \\
\hline & $\begin{array}{c}\text { People } \\
\text { management }\end{array}$ & $\begin{array}{l}\text { Leading people (ID5, ID11, ID14) } \\
\text { Supervision (ID9) } \\
\text { Motivation and guidance (ID9, ID14) } \\
\text { Creating positive atmosphere (ID9) } \\
\text { Delegation (ID14) } \\
\text { Managing change (ID5, ID9) }\end{array}$ \\
\hline & $\begin{array}{c}\text { Working } \\
\text { with others }\end{array}$ & $\begin{array}{l}\text { Collaboration (ID3, ID5, ID9) } \\
\text { Teamwork (ID3, ID5, ID11, ID14) } \\
\text { Relationship building (ID5, ID14) } \\
\text { Valuing diversity (ID5,ID11) } \\
\text { Integrity and building trust (ID11) }\end{array}$ \\
\hline & Communication & $\begin{array}{l}\text { Oral and written communication (ID5, ID9, ID11) } \\
\text { Using media and forums to inform and educate (ID5) } \\
\text { Using visual representations of data (ID5) }\end{array}$ \\
\hline 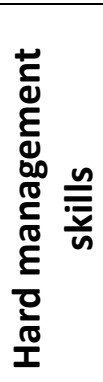 & $\begin{array}{l}\text { Managing } \\
\text { the Business }\end{array}$ & $\begin{array}{l}\text { Knowledge of the business, policy, law (ID5, ID9, ID11, } \\
\text { ID14) } \\
\text { Strategic planning (ID9, ID11) } \\
\text { Operational planning (ID9) } \\
\text { Resource mobilisation (ID5) } \\
\text { Evidence-based decision making (ID5, ID9, ID11) } \\
\text { Systems change (ID3) }\end{array}$ \\
\hline
\end{tabular}

\footnotetext{
${ }^{1}$ The scoping literature review used the four phase flow diagram from the PRISMA statement (Figure 1). The PRISMA statement provides a checklist/protocol for reporting the process of identifying and selecting publications for systematic literature reviews, as well as systematic reviews of other types of research, including evaluations of interventions (such as this scoping review). [21] In brief, Figure 1 shows the number of publications identified through the database search (2152), and through other sources (3). Using the PRISMA flow diagram, it can be seen that a fewer number of publications were screened (1558) which sometimes is a result of mismatching through the computerised search of keywords. Next, the screening process removed duplicates (9) and publications that did not meet the criteria leaving the smaller set of articles that appeared eligible for the review. Finally, after a full paper review, the remaining publications (14) were included in the analysis. Thus, the PRISMA statement's four phase flow diagram depicts how the publications were selected for the scoping review.
} 
Table 1: Characteristics of the Management Development Program

\begin{tabular}{|c|c|c|c|c|c|c|c|c|c|c|c|c|c|c|}
\hline $\begin{array}{l}\text { ID } \\
\text { No. }\end{array}$ & $\begin{array}{l}\text { Author } \\
\text { (date) }\end{array}$ & $\begin{array}{l}\text { Program } \\
\text { Name }\end{array}$ & Country & Industry & 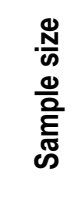 & $\begin{array}{l}\text { Management } \\
\text { Program Type }\end{array}$ & $\begin{array}{l}\text { Program } \\
\text { duration }\end{array}$ & 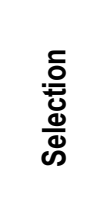 & Program Aim & $\begin{array}{l}\text { Purpose of the } \\
\text { study }\end{array}$ & $\begin{array}{l}\text { 응 } \\
\stackrel{0}{ \pm} \\
\text { ó }\end{array}$ & $\begin{array}{l}\text { Study } \\
\text { Type }\end{array}$ & 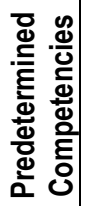 & Findings \\
\hline ID1 & $\begin{array}{l}\text { Adams \& } \\
\text { Waddle } \\
(2002) \\
\end{array}$ & $\begin{array}{l}\text { Whitbread } \\
\text { Enjoy } \\
\text { Learning }\end{array}$ & UK & Hospitality & NR & $\begin{array}{l}\text { University } \\
\text { (post graduate) }\end{array}$ & NR & NR & $\begin{array}{l}\text { Gain qualifications } \\
\text { using a project } \\
\text { driven approach }\end{array}$ & $\begin{array}{l}\text { Explore how the } \\
\text { value of the strategy } \\
\text { was assessed }\end{array}$ & $\bar{Y}$ & $\begin{array}{l}\text { Case } \\
\text { Study }\end{array}$ & $\mathrm{N}$ & $\begin{array}{l}\text { Benefits directly attributed } \\
\text { to the work-based projects }\end{array}$ \\
\hline ID2 & $\begin{array}{l}\text { Doyle } \\
\text { (2014) }\end{array}$ & $\begin{array}{l}\text { Leader's } \\
\text { Edge }\end{array}$ & Ireland & Health & 7 & $\begin{array}{l}\text { Accredited - level } \\
8 \text { module } \\
\text { (undergraduate) }\end{array}$ & 7 months & NOM & $\begin{array}{l}\text { Enhance manager } \\
\text { capacity and bring } \\
\text { about change }\end{array}$ & $\begin{array}{l}\text { Evaluate a } \\
\text { leadership training } \\
\text { program }\end{array}$ & $\bar{Y}$ & $\begin{array}{l}\text { Program } \\
\text { Evaluation } \\
\text { (Pilot) }\end{array}$ & $\mathrm{N}$ & $\begin{array}{l}\text { Action learning is effective } \\
\text { in developing leaders and } \\
\text { supporting change }\end{array}$ \\
\hline ID3 & $\begin{array}{l}\text { Wallis \& } \\
\text { Kennedy } \\
(2013)\end{array}$ & $\begin{array}{l}\text { Leadership } \\
\text { for } \\
\text { Resilience }\end{array}$ & USA & Nursing & 25 & $\begin{array}{l}\text { Education } \\
\text { Program }\end{array}$ & $\begin{array}{l}1 \text { year } \\
(4 \mathrm{x} \\
\text { residential } \\
\text { retreats })\end{array}$ & NOM & $\begin{array}{l}\text { Promoting team- } \\
\text { based approaches } \\
\text { to improve nurse } \\
\text { retention }\end{array}$ & $\begin{array}{l}\text { Assess the } \\
\text { effectiveness of the } \\
\text { training program }\end{array}$ & $\bar{Y}$ & $\begin{array}{l}\text { Program } \\
\text { Evaluation }\end{array}$ & $\bar{Y}$ & $\begin{array}{l}\text { Effectiveness is influenced } \\
\text { by leaders' emotional } \\
\text { intelligence and } \\
\text { organisational culture }\end{array}$ \\
\hline ID4 & $\begin{array}{l}\text { Omar et } \\
\text { al. }(2009)\end{array}$ & NR & $\begin{array}{l}\text { UK \& } \\
\text { Iran }\end{array}$ & Health & 23 & $\begin{array}{l}\text { Education } \\
\text { Program }\end{array}$ & $\begin{array}{l}7 \text { courses } \\
(1-10 \\
\text { weeks) } \\
\text { over } 1 \\
\text { year }\end{array}$ & NOM & $\begin{array}{l}\text { Tailored program } \\
\text { for capacity } \\
\text { building }\end{array}$ & $\begin{array}{l}\text { Evaluation to guide } \\
\text { future program } \\
\text { development }\end{array}$ & $\mathrm{N}$ & $\begin{array}{l}\text { Program } \\
\text { Evaluation }\end{array}$ & $\mathrm{N}$ & $\begin{array}{l}\text { Training evaluations should } \\
\text { assess learning and } \\
\text { communicate results }\end{array}$ \\
\hline ID5 & $\begin{array}{l}\text { Saleh et } \\
\text { al. (2004) }\end{array}$ & NEPHLI & USA & $\begin{array}{l}\text { Public } \\
\text { Health }\end{array}$ & 81 & $\begin{array}{l}\text { University } \\
\text { modules }\end{array}$ & 1 year & ALL & $\begin{array}{l}\text { To improve the } \\
\text { leadership skills }\end{array}$ & $\begin{array}{l}\text { Evaluate program } \\
\text { effectiveness } \\
\text { against } \\
\text { predetermined } \\
\text { competencies }\end{array}$ & $\mathrm{N}$ & $\begin{array}{l}\text { Program } \\
\text { Evaluation }\end{array}$ & $\bar{Y}$ & $\begin{array}{l}\text { Participants' skill level } \\
\text { improved across all } 15 \\
\text { competency areas }\end{array}$ \\
\hline ID6 & $\begin{array}{l}\text { West et } \\
\text { al. (2016) }\end{array}$ & $\begin{array}{l}\text { Nurses } \\
\text { Emerging as } \\
\text { Leaders }\end{array}$ & USA & Nursing & 75 & $\begin{array}{l}\text { Education } \\
\text { Program }\end{array}$ & $\begin{array}{l}1 \text { year } \\
\text { (8-hours } \\
\text { every 4-6 } \\
\text { weeks) }\end{array}$ & NOM & $\begin{array}{l}\text { Preparing nurse } \\
\text { leaders for role } \\
\text { transition and } \\
\text { leadership }\end{array}$ & $\begin{array}{l}\text { Evaluate participant } \\
\text { competency } \\
\text { improvements } \\
\text { compared with non- } \\
\text { participants }\end{array}$ & $\bar{Y}$ & $\begin{array}{l}\text { Program } \\
\text { Evaluation }\end{array}$ & $\bar{Y}$ & $\begin{array}{l}\text { The program improves } \\
\text { succession planning by } \\
\text { developing leaders who are } \\
\text { prepared for leadership } \\
\text { positions }\end{array}$ \\
\hline ID7 & $\begin{array}{l}\text { Throgmor- } \\
\text { ton et al. } \\
(2016)\end{array}$ & $\begin{array}{l}\text { Physician } \\
\text { Leadership } \\
\text { Academy }\end{array}$ & USA & Health & 21 & $\begin{array}{l}\text { Education } \\
\text { Program }\end{array}$ & 10 months & NR & $\begin{array}{l}\text { To develop strong } \\
\text { physician leaders } \\
\text { in healthcare }\end{array}$ & $\begin{array}{l}\text { Outline evaluation } \\
\text { strategy and } \\
\text { inaugural program } \\
\text { outcomes }\end{array}$ & $\bar{Y}$ & $\begin{array}{l}\text { Program } \\
\text { Evaluation }\end{array}$ & $\mathrm{N}$ & $\begin{array}{l}\text { The program met targeted } \\
\text { outcomes across all levels } \\
\text { of evaluation }\end{array}$ \\
\hline ID8 & Berg \& & Coaching & NR & Fortune 500 & 59 & Education & $5 \times 2$-day & NR & Change behaviour & Examine the effect & $Y$ & Case & $\mathrm{N}$ & Participants learned a \\
\hline
\end{tabular}




\begin{tabular}{|c|c|c|c|c|c|c|c|c|c|c|c|c|c|c|}
\hline & $\begin{array}{l}\text { Karlsen } \\
\text { (2012) }\end{array}$ & & & company & & Program & seminars & & $\begin{array}{l}\text { to improve use of } \\
\text { manager's toolbox }\end{array}$ & $\begin{array}{l}\text { of coaching on } \\
\text { leadership } \\
\text { development }\end{array}$ & & Study & & $\begin{array}{l}\text { variety of solutions from the } \\
\text { manager's toolkit }\end{array}$ \\
\hline ID9 & $\begin{array}{l}\text { Supic et } \\
\text { al. }(2010)\end{array}$ & $\begin{array}{l}\text { Project for } \\
\text { capacity } \\
\text { building }\end{array}$ & Serbia & Health & 107 & $\begin{array}{l}\text { University } \\
\text { modules }\end{array}$ & $1-2$ years & NOM & $\begin{array}{l}\text { Improve particular } \\
\text { management } \\
\text { skills }\end{array}$ & $\begin{array}{l}\text { Identify } \\
\text { improvements and } \\
\text { explore predictors } \\
\text { and relationships }\end{array}$ & $Y$ & $\begin{array}{l}\text { Cohort } \\
\text { Study }\end{array}$ & $Y$ & $\begin{array}{l}\text { Training programs can } \\
\text { improve competencies } \\
\text { which improves competitive } \\
\text { advantage }\end{array}$ \\
\hline ID10 & $\begin{array}{l}\text { Steensma } \\
\& \text { Groen- } \\
\text { eveld } \\
(2010)\end{array}$ & NR & $\begin{array}{l}\text { Nether- } \\
\text { lands }\end{array}$ & Government & 54 & NR & NR & $\begin{array}{l}\mathrm{NR} \\
\mathrm{CG}\end{array}$ & $\begin{array}{l}\text { Improve growth, } \\
\text { knowledge, and } \\
\text { performance }\end{array}$ & $\begin{array}{l}\text { Demonstrate the } \\
\text { value of } \\
\text { experimental } \\
\text { designs in } \\
\text { evaluation studies }\end{array}$ & $\mathrm{N}$ & $\begin{array}{l}\text { Experimen } \\
\text { tal with a } \\
\text { control } \\
\text { group }\end{array}$ & $\mathrm{N}$ & $\begin{array}{l}\text { Demonstrated 'good' } \\
\text { management behaviours; } \\
\text { differences in knowledge } \\
\text { acquisition but not in } \\
\text { behaviour }\end{array}$ \\
\hline ID11 & $\begin{array}{l}\text { Hayes } \\
(2007)\end{array}$ & $\begin{array}{l}\text { Dimensions } \\
\text { Leadership } \\
\text { Program }\end{array}$ & Canada & Gaming & 258 & $\begin{array}{l}\text { Pathway to } \\
\text { certificate in } \\
\text { management }\end{array}$ & $\begin{array}{l}2 \text { week } \\
\text { training } \\
\text { sessions }\end{array}$ & ALL & $\begin{array}{l}\text { Build existing } \\
\text { skills and build } \\
\text { stronger leaders }\end{array}$ & $\begin{array}{l}\text { Evaluation of a } \\
\text { leadership } \\
\text { development } \\
\text { initiative }\end{array}$ & $\mathrm{N}$ & $\begin{array}{l}\text { Case } \\
\text { Study }\end{array}$ & $Y$ & $\begin{array}{l}\text { Positive impact on the } \\
\text { leadership competency; } \\
\text { positive impact on KPIs }\end{array}$ \\
\hline ID12 & $\begin{array}{l}\text { Fealy et } \\
\text { al. }(2015)\end{array}$ & $\begin{array}{l}\text { Clinical } \\
\text { Leadership } \\
\text { Development }\end{array}$ & Ireland & Nursing & 70 & $\begin{array}{l}\text { Education } \\
\text { Program } \\
\text { (including } \\
\text { mentoring / } \\
\text { coaching) } \\
\end{array}$ & 6 months & NR & $\begin{array}{l}\text { Individual and } \\
\text { service level } \\
\text { development } \\
\text { improvements }\end{array}$ & $\begin{array}{l}\text { Evaluation of } \\
\text { leadership } \\
\text { development } \\
\text { programs }\end{array}$ & $\mathrm{Y}$ & $\begin{array}{l}\text { Case } \\
\text { Study } \\
\text { (Pilot) }\end{array}$ & $\mathrm{N}$ & $\begin{array}{l}\text { Clinical leadership } \\
\text { development can impact on } \\
\text { service in distinct and } \\
\text { identifiable ways }\end{array}$ \\
\hline ID13 & $\begin{array}{l}\text { Yaping \& } \\
\text { Staton } \\
(2002)\end{array}$ & $\begin{array}{l}\text { Health } \\
\text { management } \\
\text { Training } \\
\text { Course }\end{array}$ & China & Health & 233 & $\begin{array}{l}\text { Program formally } \\
\text { recognised by } \\
\text { the Hospital } \\
\text { Accreditation } \\
\text { Committee }\end{array}$ & $\begin{array}{l}2 \text { years } \\
\text { (part-time) }\end{array}$ & NR & $\begin{array}{l}\text { Improve } \\
\text { understanding of } \\
\text { management, skills } \\
\text { and efficiency of } \\
\text { the health sector }\end{array}$ & $\begin{array}{l}\text { Evaluate the impact } \\
\text { of training in } \\
\text { management } \\
\text { practice }\end{array}$ & $Y$ & $\begin{array}{l}\text { Program } \\
\text { Evaluation }\end{array}$ & $\mathrm{N}$ & $\begin{array}{l}\text { Positively impacted on } \\
\text { health management } \\
\text { practices and made a } \\
\text { significant contribution to } \\
\text { management education }\end{array}$ \\
\hline ID14 & $\begin{array}{l}\text { Holmberg } \\
\text { et al. } \\
(2016)\end{array}$ & $\begin{array}{l}\text { Leadership } \\
\text { Development } \\
\text { Program }\end{array}$ & Sweden & Insurance & 107 & $\begin{array}{l}\text { Education } \\
\text { Program }\end{array}$ & $\begin{array}{l}12 \text { days } \\
\text { ( } 2-3 \text { day } \\
\text { residential } \\
\text { seminars) }\end{array}$ & $\begin{array}{l}\text { NOM } \\
\text { SS } \\
\text { CG }\end{array}$ & $\begin{array}{l}\text { Increase } \\
\text { participants' } \\
\text { leadership skills } \\
\text { and capacities }\end{array}$ & $\begin{array}{l}\text { Evaluate a } \\
\text { leadership } \\
\text { development } \\
\text { program }\end{array}$ & $\mathrm{Y}$ & $\begin{array}{l}\text { Program } \\
\text { Evaluation }\end{array}$ & $\mathrm{Y}$ & $\begin{array}{l}\text { Outcomes were } \\
\text { meaningfully operationalised } \\
\text { for generic skills and health } \\
\text { and wellbeing }\end{array}$ \\
\hline
\end{tabular}

ALL = All; CG = Control Group; EVAL = Evaluation study; N = No; NEPHLI = Northeast Public Health Leadership Institute leadership training; NOM = Nominated; NR = Not reported; SS = Self-selected; Y = Yes 
Table 3: CQI approaches for determining impact for management training programs.

\begin{tabular}{|c|c|c|c|c|c|c|c|c|c|c|c|}
\hline $\begin{array}{l}\text { ID } \\
\text { No. }\end{array}$ & $\begin{array}{l}\text { Author } \\
\text { (Date) }\end{array}$ & $\begin{array}{c}\text { CQI } \\
\text { Approach }\end{array}$ & $\begin{array}{l}\text { Purpose of } \\
\text { Evaluation }\end{array}$ & 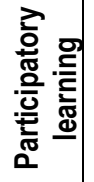 & 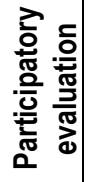 & $\begin{array}{l}\overleftarrow{d} \\
\frac{d}{0} \\
\bar{\alpha} \\
\bar{d}\end{array}$ & 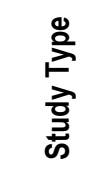 & $\begin{array}{l}\text { Impact Level } \\
\text { Evaluated }\end{array}$ & Impact Reported & 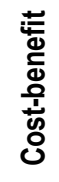 & Evaluation recommendations \\
\hline ID1 & $\begin{array}{l}\text { Adams \& } \\
\text { Waddle } \\
(2002)\end{array}$ & $\begin{array}{l}\text { Action } \\
\text { Learning }\end{array}$ & $\begin{array}{l}\text { Evaluate the returns } \\
\text { from the program }\end{array}$ & Y & $\mathrm{N}$ & Y & MMR & $\begin{array}{l}\text { Individual } \\
\text { Organisational }\end{array}$ & $\begin{array}{l}\text { Benefits were directly } \\
\text { attributable to the work-based } \\
\text { projects; financial savings }\end{array}$ & Y & $\begin{array}{l}\text { Action Learning is a powerful tool for relevant } \\
\text { knowledge to be brought to the workplace and } \\
\text { helps personal learning and transformation }\end{array}$ \\
\hline ID2 & Doyle (2014) & $\begin{array}{l}\text { Action } \\
\text { Learning \& } \\
\text { Reflective } \\
\text { Practice }\end{array}$ & $\begin{array}{l}\text { Evaluate the returns } \\
\text { from the program }\end{array}$ & $Y$ & Y & Y & Qual & $\begin{array}{l}\text { Individual } \\
\text { Organisational }\end{array}$ & $\begin{array}{l}\text { Improved leadership skills. } \\
\text { Projects had positive impacts }\end{array}$ & $Y$ & $\begin{array}{l}\text { The project must be sufficiently difficult to } \\
\text { promote learning, the mix of participants, and } \\
\text { organisational commitment is crucial. }\end{array}$ \\
\hline ID3 & $\begin{array}{l}\text { Wallis \& } \\
\text { Kennedy } \\
(2013)\end{array}$ & $\begin{array}{l}\text { CQI Projects - } \\
\text { plan, develop, } \\
\text { implement and } \\
\text { evaluate. }\end{array}$ & $\begin{array}{l}\text { Can differences be } \\
\text { attributed to the LR } \\
\text { training? }\end{array}$ & Y & $\mathrm{N}$ & Y & MMR & $\begin{array}{l}\text { Individual } \\
\text { Team } \\
\text { Organisation }\end{array}$ & $\begin{array}{l}\text { Success at the team level } \\
\text { was affected by success at } \\
\text { the individual and } \\
\text { organisational level }\end{array}$ & Y & $\begin{array}{l}\text { Evaluation suggests that success of the program } \\
\text { may be more directly related to selection of } \\
\text { teams and to organisation's commitment than to } \\
\text { the ideas proposed by individuals. }\end{array}$ \\
\hline ID4 & $\begin{array}{l}\text { Omar et al } \\
(2009)\end{array}$ & $\begin{array}{l}\text { Staged } \\
\text { approach with } \\
\text { continuous } \\
\text { learning }\end{array}$ & $\begin{array}{l}\text { To evaluate reaction, } \\
\text { learning, application } \\
\text { and organisational } \\
\text { impact }\end{array}$ & Y & $\mathrm{N}$ & $\mathrm{N}$ & MMR & $\begin{array}{l}\text { Individual } \\
\text { Organisational }\end{array}$ & $\begin{array}{l}\text { Participant satisfaction with } \\
\text { the training; } 81 \% \text { could } \\
\text { perform their jobs better }\end{array}$ & $\mathrm{N}$ & $\begin{array}{l}\text { Consistent use of evaluation over time for } \\
\text { comparisons }\end{array}$ \\
\hline ID5 & $\begin{array}{l}\text { Saleh et al. } \\
(2004)\end{array}$ & $\begin{array}{l}\text { Post training } \\
\text { evaluation }\end{array}$ & $\begin{array}{l}\text { Evaluate program's } \\
\text { effectiveness against } \\
\text { predetermined } \\
\text { competencies }\end{array}$ & $\mathrm{N}$ & $\mathrm{N}$ & $\mathrm{N}$ & Quant & $\begin{array}{c}\text { Individual } \\
\text { (program level) }\end{array}$ & $\begin{array}{l}\text { Good long-term outcomes } \\
\text { (e.g. PhDs and occupations) }\end{array}$ & $\mathrm{N}$ & $\begin{array}{l}\text { Public Health leadership training programs are } \\
\text { effective in improving skills }\end{array}$ \\
\hline ID6 & $\begin{array}{l}\text { West et al. } \\
(2016)\end{array}$ & $\begin{array}{l}\text { Post training } \\
\text { evaluation }\end{array}$ & $\begin{array}{l}\text { Evaluation of } \\
\text { program } \\
\text { effectiveness }\end{array}$ & Y & $\mathrm{N}$ & $\mathrm{N}$ & Quant & $\begin{array}{l}\text { Individual } \\
\text { Organisation }\end{array}$ & $\begin{array}{l}\text { Improves morale, succession } \\
\text { planning and personal } \\
\text { satisfaction }\end{array}$ & $\mathrm{N}$ & $\begin{array}{l}\text { Further evaluation is required to ensure the } \\
\text { content remains current, and that individual and } \\
\text { organisational needs are met. }\end{array}$ \\
\hline ID7 & $\begin{array}{l}\text { Throgmorton } \\
\text { et al. } \\
(2016)\end{array}$ & Best practice & $\begin{array}{l}\text { Evaluation of } \\
\text { program } \\
\text { effectiveness }\end{array}$ & $\mathrm{N}$ & $\mathrm{N}$ & $\mathrm{N}$ & MMR & $\begin{array}{l}\text { Individual } \\
\text { Organisational }\end{array}$ & $\begin{array}{l}\text { Continued engagement post } \\
\text { training }\end{array}$ & Y & $\begin{array}{l}\text { Following participants over time would yield more } \\
\text { information on long-term impact of leadership } \\
\text { development programs. }\end{array}$ \\
\hline ID8 & $\begin{array}{l}\text { Berg \& } \\
\text { Karlsen } \\
(2012)\end{array}$ & $\begin{array}{l}\text { Learn-Apply- } \\
\text { Feedback- } \\
\text { Review Cycle }\end{array}$ & $\begin{array}{l}\text { Setting the context, } \\
\text { and reflecting on the } \\
\text { meaning of the } \\
\text { experience. }\end{array}$ & Y & Y & $\mathrm{N}$ & Qual & $\begin{array}{l}\text { Individual } \\
\text { Organisational }\end{array}$ & $\begin{array}{l}\text { Participants can learn to } \\
\text { solve real work challenges } \\
\text { through coaching }\end{array}$ & Y & $\begin{array}{l}\text { Future research should apply a comprehensive } \\
\text { research design (e.g. control group).Supervisors } \\
\text { and subordinates should be involved in the } \\
\text { training process }\end{array}$ \\
\hline
\end{tabular}




\begin{tabular}{|c|c|c|c|c|c|c|c|c|c|c|c|}
\hline ID9 & $\begin{array}{l}\text { Supic et al. } \\
(2010)\end{array}$ & $\begin{array}{l}\text { Pre/Post } \\
\text { training } \\
\text { evaluation }\end{array}$ & $\begin{array}{l}\text { Identify } \\
\text { improvements }\end{array}$ & $Y$ & $\mathrm{~N}$ & $\mathrm{~N}$ & Quant & Individual level & $\begin{array}{l}\text { The time in the management } \\
\text { position influenced individual } \\
\text { skill improvements; } \\
\text { influenced by duration as a } \\
\text { manager }\end{array}$ & $\mathrm{N}$ & $\begin{array}{l}\text { Study can be improved with data other than self- } \\
\text { reported and having a control group }\end{array}$ \\
\hline ID10 & $\begin{array}{l}\text { Steensma \& } \\
\text { Groeneveld } \\
(2010)\end{array}$ & $\begin{array}{l}\text { Evaluation - } \\
\text { pre, during and } \\
\text { post program }\end{array}$ & $\begin{array}{l}\text { Program } \\
\text { effectiveness }\end{array}$ & $Y$ & $\mathrm{~N}$ & $\mathrm{~N}$ & Quant & $\begin{array}{l}\text { Individual } \\
\text { Organisational }\end{array}$ & $\begin{array}{l}\text { No long term outcomes } \\
\text { reported }\end{array}$ & $\mathrm{N}$ & $\begin{array}{l}\text { The 4-levels method gives detailed insights in } \\
\text { results }\end{array}$ \\
\hline ID11 & $\begin{array}{l}\text { Hayes } \\
(2007)\end{array}$ & $\begin{array}{l}\text { Action Plans } \\
\text { to foster CQI }\end{array}$ & $\begin{array}{l}\text { Examine the level } \\
\text { impact of training }\end{array}$ & $\mathrm{N}$ & $\mathrm{N}$ & $\mathrm{N}$ & MMR & $\begin{array}{l}\text { Individual } \\
\text { Organisational }\end{array}$ & No & $\mathrm{N}$ & $\begin{array}{l}\text { Preplanning for the evaluation process was } \\
\text { critical to ensure a comprehensive program } \\
\text { evaluation }\end{array}$ \\
\hline ID12 & $\begin{array}{l}\text { Fealy et al. } \\
(2015)\end{array}$ & $\begin{array}{l}\text { Action learning, } \\
\text { Service } \\
\text { Assessment } \\
\text { Tool (SAT) }\end{array}$ & $\begin{array}{l}\text { Evaluate the } \\
\text { program's service } \\
\text { impact }\end{array}$ & $Y$ & $\mathrm{~N}$ & $\mathrm{~N}$ & Qual & $\begin{array}{c}\text { Individual } \\
\text { Organisational }\end{array}$ & $\begin{array}{l}\text { Direct impact related to } \\
\text { projects and indirect impact } \\
\text { arising from the program } \\
\text { participation }\end{array}$ & $\mathrm{N}$ & $\begin{array}{l}\text { Service user data is needed to examine service } \\
\text { impact. Time bound studies cannot establish } \\
\text { long-term impact }\end{array}$ \\
\hline ID13 & $\begin{array}{l}\text { Yaping \& } \\
\text { Stanton } \\
(2002)\end{array}$ & $\begin{array}{l}\text { Post training } \\
\text { evaluation }\end{array}$ & $\begin{array}{l}\text { To improve the } \\
\text { training program }\end{array}$ & $\mathrm{N}$ & $\mathrm{N}$ & $\mathrm{N}$ & MMR & Individual & $\begin{array}{l}\text { Impact limited by workplace } \\
\text { factors }\end{array}$ & $\mathrm{N}$ & $\begin{array}{l}\text { The findings will be of interest to other health } \\
\text { service management programs but cannot be } \\
\text { generalised }\end{array}$ \\
\hline ID14 & $\begin{array}{l}\text { Holmberg et } \\
\text { al. } \\
(2016)\end{array}$ & $\begin{array}{l}\text { Pre/Post } \\
\text { training } \\
\text { evaluation }\end{array}$ & $\begin{array}{l}\text { Increase workforce } \\
\text { health / wellbeing }\end{array}$ & $Y$ & $\mathrm{~N}$ & $\mathrm{~N}$ & Quant & Individual & $\begin{array}{l}\text { Significant increase in self- } \\
\text { reported LSE and PS; there } \\
\text { may be a positive effect on } \\
\text { health and wellbeing }\end{array}$ & $\mathrm{N}$ & $\begin{array}{l}\text { Leadership evaluation programs can be } \\
\text { evaluated within a framework of generic } \\
\text { leadership skills and health-related outcomes } \\
\text { supporting more theoretically anchored learning }\end{array}$ \\
\hline
\end{tabular}

Behaviour Response Inventory (BRI) (Schutte \& Mellen 1999); Leadership Practices Inventory (LPI) (Koues \& Posner 2007); Life Orientation Test - Revised (Scheirer et al 1994); LSE = leadership self-efficacy; Mixed Methods Research (MMR); N = No; PS = Political skills; Qualitative Research (Qual); Quantitative Research (Quant); RIHEL = Imputed Regional Institute for Health and Environmental Leadership (RIHEL) programme change model; $S O C=$ Sense of Coherence; $Y=$ Yes. 